\title{
Reversing the Trend of Dismal Performance in Disadvantaged Schools: A Curriculum Evaluation exercise
}

\author{
Mutendwahothe Walter Lumadi \\ Department of Curriculum and Instruction, College of Education, \\ University of South Africa, South Africa
}

Doi:10.5901/mjss.2014.v5n6p243

\begin{abstract}
The deficit of science and mathematics skills is a national problem of such magnitude that it has been, and still is, the subject of heated debates. For the past few years, the Grade 12 results have reflected a worrying trend of a high dropout rate at school level and low performance in these gateway subjects. The College of Education at the University of South Africa (Unisa) has started an MIT Community Engagement Project aimed at reversing the high failure rate in the deep rural areas of the disadvantaged schools in the Vhembe district of the Limpopo and North West provinces (NW). With the assistance of the provincial department of education, experts were identified and they signed a two-year contract with Unisa for teaching mathematics and science at these disadvantaged schools over weekends and during the holidays. An honorarium was set aside to compensate for the transport and tuition fees for these experts from dinaledi (stars) schools. Based on the year-end examination results, further suggestions for a turnaround strategy were formulated.
\end{abstract}

Keywords: failure rate, disadvantaged schools, curriculum review, dinaledi, MIT, Unisa

\section{Introduction}

Unisa introduced a policy to implement a Community Engagement Project. This policy requires academics to reach out to communities in times of need. In this study, the researcher reports on the preliminary findings at various secondary schools in the rural area. The project leader has a team of experienced academics driving the project focusing on the dismal performance of Grade 12 students in mathematics and science in the Vhembe district of the Limpopo and NW provinces.

Academics view mathematics as a gateway to future professions in a variety of fields such as medicine, engineering, accounting and others. Every area of mathematics has its own unique applications to different career options. At institutions of higher learning, most of the curricula require science and mathematics, because the ability to master these skills is an important indicator of potential for students' success at all levels of academic endeavour. Students who enter university with good symbols in the gateway subjects tend to do well compared to those who just manage to gain admission with poor symbols. These weak students generally struggle and ultimately drop out because they lack a solid foundation even after passing the National Senior Certificate Examinations. International research studies have reported underachievement in mathematics and the science subjects (Fullan, 2005, Carl 2002 \& Hoadley, 2009).

\section{Literature Review}

Researchers around the globe are implementing various hands-on strategies to address students' poor performance in these critical subjects. It was reported that in Singapore, a group of researchers at Nanyang Technological University (Goody \& Brophy, 2003) suggested improvements to curriculum and teaching strategies, the use of technology, infusing thinking and creativity and provision of training as solutions to improve calculus and mathematics education. The above study reported on students' development in mathematical understanding through investigation and exploration tasks in the classroom by using a specific teaching unit which the researcher had established. The shortage of qualified science and mathematics teachers is a growing problem worldwide. Not only is there a shortage of teachers, but the teaching of science and mathematics in the USA is also failing to equip future generations with analytical skills. This deficiency in student achievement was documented by the Third International Mathematics and Science Study in which US fourth graders ranked above the international average in science and mathematics, eighth graders were in the middle of the field and graduating high school students ranked well below the international average (Beane, 2005) 
As the shortage of science and mathematics teachers increases, more schools are employing underqualified teachers. Although most teachers have a teaching diploma in science or mathematics, many of them do not have any teaching experience. Hence these provisionally licensed science and mathematics teachers face the extra challenge of learning how to teach on their own. With the growing shortage of teachers, the number of underprepared teachers entering the profession is increasing. More than $12 \%$ of new hires begin teaching without any formal pedagogical training, and $26 \%$ of new hires do not meet the licensing requirements in their respective states. Many of these new and underprepared teachers teach in extremely poor schools, especially in rural areas (Finch \& Crunkilton, 2004).

\section{Method}

A qualitative approach was employed in the project. A full-time Grade 12 cohort in dysfunctional schools in the Vhembe district in Limpopo and NW provinces was the population in the research project. The population comprised learners who were repeating matric after failing mathematics and science dismally. These students were purposefully sampled on the basis of their previous year's examination marks ranging from 0 to $10 \%$. Moreover, the teachers who were unable to produce satisfactory results for these subjects made themselves available for the interviews. In this community engagement project, the Department of Education was requested to identify experts who have a good track record of producing good results at their schools to come and teach at the identified disadvantaged schools over weekends and during the school vacations. Experienced teachers from dinaledi (little stars) were briefed about their expectations before committing themselves (See table 1 for Saturday classes' intervention).

A contract was signed with these teachers which would enable them to be remunerated for rendering their services by Unisa's Department of Curriculum and Instructional Studies. An honorarium was used to pay for transport to the various schools on Saturdays and Sundays and teaching from 08:00 to 15:00, with a lunch break. Prior to starting their teaching, they mapped the way forward on what was supposed to be included in the pace setter for Saturday classes (see table 1).

Table 1: Pace setter for saturday classes

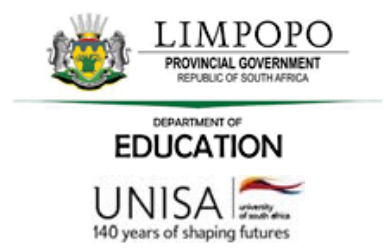

Unisa Maths and Science Intervention Programme

\begin{tabular}{|c|c|c|}
\hline Date & Physical Science & Mathematics \\
\hline 27 April & $\begin{array}{l}\text { - Kc Calculations } \\
\text { - Application of Le Chatelier's Principle } \\
\text { - Graphs interpretations }\end{array}$ & $\begin{array}{l}\text { - Algebraic manipulations } \\
\text { - Patterns and sequences }\end{array}$ \\
\hline 04 May & $\begin{array}{l}\text { - Vertical Projectile Motion } \\
\text { - Work-Energy Theorem }\end{array}$ & $\begin{array}{l}\text { - Calculus } \\
\text { - Functions and Inverses }\end{array}$ \\
\hline 11 May & $\begin{array}{l}\text { - E cell } \\
\text { - Electrolysis - Aluminium extraction } \\
\text { - Organic Reactions and Physical Properties of Organic } \\
\text { molecules }\end{array}$ & $\begin{array}{l}\text { - Trigonometry } \\
\text { - Coordinate geometry }\end{array}$ \\
\hline
\end{tabular}

All the teachers had to adhere to the proposed schedule and there were monitoring mechanisms in place. Teachers from the disadvantaged schools were requested to attend classes with their students over the weekends for the sake of selfempowerment when the experts were presenting the classes. This was done to maintain discipline because the experts did not know the learners in the struggling schools. The research instruments comprised monthly tests, quarterly tests, June tests, trial tests and final year examinations.

\section{Findings and Discussion}

This section reports the findings of the data analysis and interpretation that were conducted to document the root cause 
of the dismal performance in mathematics and science subjects and the miracle needed to solve the problem. In order to go beyond a restatement of the truism that academic difficulties are rooted in the inequalities in schooling, it was necessary to explain the failure (and by implication, success) in conceptual terms in an effort to promote innovation and development in the teaching-learning situation.

\subsection{Theme 1: Facilities barrier}

According to Marsh (2002), facilities can be physical, human or financial. Teaching and learning cannot occur in an environment that is lackadaisical, unpredictable and lacks structure because such an atmosphere is not conducive to optimising quality classroom time (See figure 1 for a Grade 12 mathematics and science classroom). Schools in the NW serve both a mix of affluent and poor neighbourhoods, which means that there may be an opportunity gap in which the more wealthy students have better resources than the other learners, which enable them to achieve better outcomes. In the analysis of data, it became evident that some of the teachers in the NW had better credentials and were more experienced and talented than others.

The participants reported that conditions in some of the schools were not conducive to learning for substantial periods of time. Interviewee $\mathrm{H}$ from Dr Kenneth Kaunda School stated the following:

"In our school, it is pathetic for us as teachers to use the toilet of a School Governing Body closer to the school. In most schools without toilets, both teachers and students used the bushes closer to the school which caused an unhealthy stench. What exacerbates the situation is a shortage of water in the schools. There is no running water to wash hands after students and teachers had relieved themselves. Although extreme cases of students dying from cholera and tuberculosis were reported to the Ministry of Health, to date nothing has been done yet"

Figure 1: A grade 12 classroom for mathematics and science

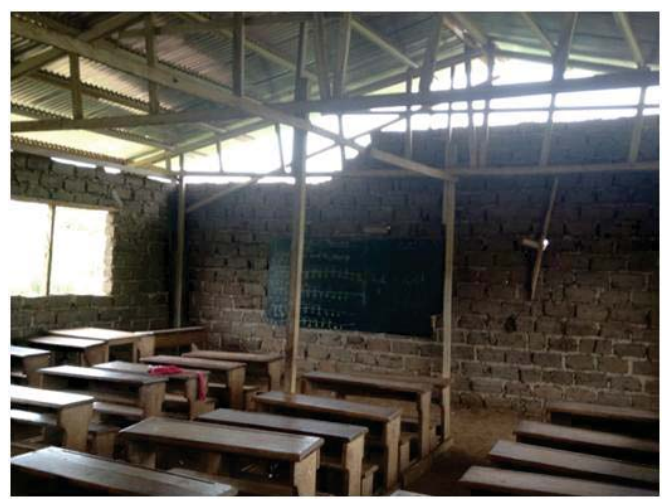

As long as the allocation of resources remains as skewed as it is, where the majority of rural schools are dilapidated with thatched grass, no running water, no modern technical equipment, no affordable transport for both students and teachers and no toilets, effective teaching will be a pipedream. According to the Bill of Rights, the state has an obligation, through reasonable measures, to make education progressively available and accessible. Until policy makers focus their time and attention on this dire problem, learners in the poorest provinces will continue to suffer (DoE, 1998 \& Goodson, 1988).

Interviewees C and D, from Ngaka Modiri Molema School, also reported the following shocking cases relating to the unavailability of toilets in some of the schools in the NW province.

"It is embarrassing to report that in our school, we do not have toilets. The first case concerned a student who was bitten by a cobra in the bush whilst relieving herself during break. She ended up in clinic for first aid treatment. The second case involved a female teacher who was raped in the bush. The last one involved a student from a school closer to the border with Botswana who was unfortunately devoured by a lion in the same bush. Our staff members with all the students attended the student's funeral."

Nineteen years into our democracy, it is a travesty that these kinds of challenges are still faced in South African schools. Many teachers are running out of patience. An interviewee from Mafikeng was extremely emotional as she 
recounted her story:

"Most classrooms in this school as you can see have broken windows, peeling paint, cracked walls, old furniture, and no doors. That building over there is collapsing, this class's roof is leaking and you will think a tap of water is opened once it starts raining. We are compelled to cancel classes during the winter and summer seasons. It was disturbing to find that in four schools the teacher ratio ranged from 1:125 to 1:202."

Figure 2: A school specialising in mathematics and science

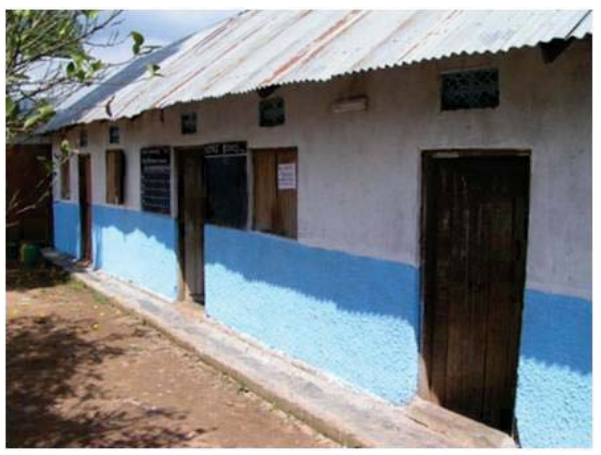

Students who attend schools in affluent areas have state-of-the-art facilities compared with those of their poorer peers in rural areas. Some of these buildings have air conditioners to be used in summer and heaters in winter. Learners in rural schools do not have all these wonderful facilities (See figure 2 for a Grade 12 mathematics and science school). Herzberg's two-factor theory assumes that happy employees produce more. What motivates one individual might be a demotivator for another individual. This does not account for individual personality traits that could provide a different response to a hygiene factor.

Teachers and learners expressed genuine concern about overcrowding in schools. This is common in many schools and it raises the following questions: How long does it take a teacher to assess the work of all these students? Is it a fair assessment? Can a teacher apply the principle of individualisation? Is there any quality assurance mechanism in place? Students are important participants in a curriculum and their voice should be recognised in curriculum development (Bender \& Jordaan, 2007). In some of the schools, the teachers were dissatisfied about the poor delivery service from the government. These teachers did not even have a staffroom. Instead, they stored their possessions in their cars for safety. Those who had staffrooms had old furniture with broken chairs and tables shared among them. One wonders whether democracy is about what is currently witnessed in most schools. It would appear that democracy is meant for the chosen few. Despite these challenges, teachers are expected to be productive. When students fail, the teachers are the scapegoats and they have to explain the low pass rate. Very few teachers can carry on indefinitely in schools in these poor working conditions. It was reported that computers were delivered to some of the schools. The irony is that the schools did not have electricity. At these schools, data have to be captured manually. Schedules also have to be prepared manually. Tests are still written on the chalkboard (see figure below of a rural school).

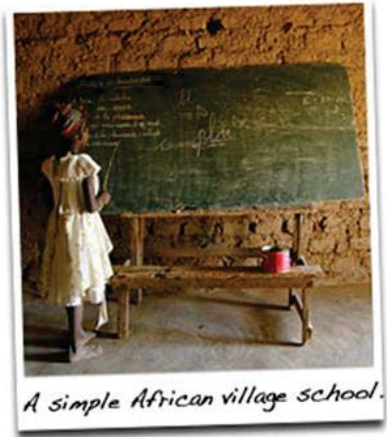


In contrast to urban schools, rural schools do not often receive the necessary support from the Education Department. Although resources have been poured into public schools to redress inequalities and improve standards, according to Pirozzi (2009), UNICEF takes a step further by indicating that the legacy of parallel education system still remains. On the one hand, there are many rural peri-urban and township schools that are cash-strapped and lack the basics such as running water and sanitation, and they are often targets of crime and vandalism. On the other hand, there are the wellresourced former Model "C" schools, with computer and science laboratories, sports fields, swimming pools and wellequipped libraries and highly qualified teaching staff. At these schools, the teachers and students have access to email and internet facilities (Nzimande, 1997).

Teachers and students at rural schools have less access to free afterschool programmes such as those provided for underprivileged youth in urban centres. There are several reasons for this. In addition, there is a lack of local resources, community centres and access to public transportation, which limits what learners can do after school. Even where programmes are available, many students are expected to help with farm work and do not have time for sport and other activities. Some of the learners in rural schools cannot go to schools on Fridays because of the unavailability of transport. This compels teachers to revise the work for the sake of those students who have missed classes. These disparities in the school system mirror South Africa's economic disparities. The country has one of the world's most unequal societies, with a Gini coefficient of 0.64 . The majority of South Africans live in poverty and deprivation while the minority enjoy relative wealth and all the advantages of a technologically advanced society (Coutts, 1992).

It is time for the Minister of Basic Education to urgently address the situation. The Ministerial budget proposal for 2011 contained sweeping changes to funding of primary and secondary education. New rules would radically alter the guidelines for the distribution of funding to schools with high concentrations of low-income learners, compelling schools to account for the poor grade 12 results.

\subsection{Theme 2: Access and advocacy on the HIVIAIDS pandemic}

Herzberg's hygiene factors, which relate to the work setting and not the actual content of the work, include adequate wages, comfortable and safe working conditions, fair company policies and job security. Based on the statistics obtained at antenatal clinics in 2007, the Medical Research Council suggested that the prevalence of HIV infections in the general population was about $12 \%$, which meant that more than five million of 43.8 million South Africans were HIV positive (Van Wyk \& Lemmer, 2007:302). The HIV and AIDS pandemic is currently a health issue that is capturing the attention of the world. The reasons are obvious - the disease is fatal and the number of cases diagnosed in South African schools has recently reached $57.5 \%$ of the sexually active population (Statistics South Africa, 2006 \& UNAIDS, 2010). Cases of HIVIAIDS have been reported in the districts of the NW schools. The Ministry of Health is still in crisis mode as far as urgent and short-term responses are concerned. However, longer-term responses are also necessary and need to be developed to secure the mainstreaming of HIVIAIDS education and life skills education (Actuarial Society of South Africa, 2011). Interviewee J from Mafikeng commented as follows:

"I lost a lot of weight because I am HIV positive. I intend to resign from teaching because of the stigma attached to the disease. Whenever I walk, I see students pointing fingers at me. When I am in class I see students whispering at each other's ear. Some teachers do not want to shake hands with me any longer. This is really painful. I am also seeking employment in Non-Governmental Organisations which offer good medical aid schemes."

There is the potential for an increase in the infection rates among teachers if prevention among them and learners is not effective. In the absence of access to antiretroviral (ARV), the death rate could increase substantially over the decade and result in a cumulative loss of a high number of teachers. ARV treatment can drastically reduce the rise in death rates and cumulative loss of teachers. Interviewee F from Dr Ruth Segomotsi Mompati school had the following to say in this regard:

"The shortage of ARVs from local clinics drives us frantic. Travelling from rural areas to urban areas looking for ARVs is a taxing exercise. From this school to the nearest clinic, one has to travel for about 250 kilometres to acquire this medication which is hardly found. Every weekend, students in school uniforms are seen in graveyards burying fellow students or teachers."

According to Ebersohn and Eloff (2002:79), a consequence of the loss of a breadwinner in a home is a drastic reduction in the family's earnings and the ability to care for and protect its children, who are exposed to neglect and abuse. Dialogue is also necessary to better integrate and mainstream external resources from NGOs and other funding 
agencies into a legitimate national framework to address short- and longer-term development of HIVIAIDS education. Sex education is taught in schools as part of the wider Life Orientation curriculum which was implemented in 2002 and also covers subjects such as Guidance. According to a comparative risk assessment for South Africa, unsafe sex ranks as the number one risk factor associated with the loss of potential years of life (Goodson, 1988).

The quality of the education, however, is hindered by the lack of teacher training and unwillingness on the part of teachers and schools to provide this education. Training for Life Orientation is often provided out of school hours, which is a disincentive for teachers. The shortage of trained teachers may result in only one teacher in a school being able to teach such classes, and school management may even resist what is being taught. This has led teaching unions to call for a Life Orientation module to be included in the courses presented by all teacher training institutions. In terms of the impact of HIVIAIDS on the teaching profession, research conducted on behalf of the Education Labour Relations Council determined that $12.7 \%$ of South African teachers are HIV positive and that the prevalence was highest in the 25 to 34 age group (21.4\%) and lowest (3.1\%) in the 55 and older age group (Shisana, Peltzer, Zungu-Dirwayi \& Louw, 2005:53).

The high dropout rate in South African schools could also compromise effective HIV and sex education. This may mean it is all the more necessary to offer prevention programmes for learners while they still have to attend school and before they become sexually active. Interviewee C, from Bojanala Platinum school, stated the following:

"Participants, who were empowered with training, reported that it was mammoth task to ask teachers and students to volunteer for an HIV and AIDS test. I was sued for encouraging students to go for a test when the Ministry of Health visited their school. The case was resolved amicably in court."

The Ministry of Health is unaware of the challenge of HIVIAIDS facing schools and does not provide the necessary support to the teachers. Teachers are not sufficiently trained in terms of updated facts on and knowledge of HIVIAIDS. They also have too little access to relevant teaching material relating to HIVIAIDS. Hence the relevant curriculum is not taught. In order to reduce the high turnover rate among teachers, the government should be committed to minimising the social, economic and developmental effects of HIVIAIDS on education in schools by implementing an effective policy. This policy should contribute towards promoting effective prevention and care in the context of the public education system (Government Gazette, 2000). Teachers should be trained and provided with teaching and learning material that has been identified as acceptable practice material. A framework and evidence-based criteria for good practice in teacher training should be developed and shared at regional level.

\section{Recommendations}

\subsection{Inadequate resources and facilities}

Learners from all economic groups deserve the same quality of education regardless of the location of their schools. Disparity in resources is regrettable, but could be addressed head on if the school governing bodies could be more purposeful in their decision making and develop policies that make fairness and opportunity the highest priority. Politicians should endeavour to close the achievement gap that affects poor students in rural schools. In terms of supplies, isolated rural communities should not be constantly marginalised. The Department should compile a unified Learning and Teaching Support Material catalogue with all the relevant materials and resources required at schools. The provincial education department should set aside a capital investment budget to build new schools and upgrade and renovate existing facilities, especially in rural schools, through an effective maintenance plan. Unisa helped the disadvantaged schools by purchasing pens, pencils, note books and study guides.

\subsection{Advocacy on the HIV and AIDS pandemic}

The Department of Basic Education, in conjunction with the provincial health departments, should collaborate in addressing the HIVIAIDS pandemic in schools. A plan of action should be drawn up for implementation in all schools, to educate, inform and advocate an awareness campaign. The approach of Life Orientation (LO) is not sufficiently conceptualised and integrated into HIVIAIDS education. All LO teachers should be empowered and trained as caregivers to support and handle HIVIAIDS students in their respective schools. LO education needs to be developed and better understood in terms of its pedagogical implications, and classroom management, teaching methods, teacher training and the development of renewed teaching and learning material are critical. The development of an HIVIAIDS policy in South African schools and the design and implementation of education and awareness campaigns, as well as provision for 
AIDS counselling services should be speeded up. Some of the teachers who disclosed their status to Unisa academics were counselled and also given further advice on how to deal with the HIVIAIDS pandemic. This information was confidential and not divulged to other team members.

\section{Conclusion}

This study presented an analysis of the dismal performance of students from disadvantaged schools. The rural schools are disadvantaged in terms of resources and the HIVIAIDS status of teachers. The identified factors have negative implications for the Grade 12 mathematics and science examination results. Students with a high failure rate, the teachers from disadvantaged schools and experts from the dinaledi schools were active participants in the study. It was suggested that in future, the project should start after the first week of reopening the schools in January. Unisa was requested to provide incentives to the best and most improved students to motivate them extrinsically. Unisa also assisted with the placement of students at institutions of higher learning. The Grade 12 cohort underachieved for various reasons. There is no single intervention strategy that could possibly overcome all the obstacles experienced by underachievers. Nevertheless, teachers and students alike need to make an effort to improve the pass rate. Success or failure in mathematics and science subjects will be determined by an individual's dedication.

It is incumbent upon learners to play their part by studying hard and making an effort to consult their teachers when they have difficulties in learning. They should not leave it to the day before the examination because it is impossible for them to memorise the gateway subjects' knowledge and concepts. Science and mathematics involve the development of skills and understanding that have to be consolidated over a period of time. Without the necessary resources and healthy qualified teachers, all efforts to pass the critical subjects are futile.

\section{References}

Actuarial Society of South Africa. 2011. ASSA AIDS Model 2008 Media Release.

Bender G \& Jordaan R 2007. Student perceptions and attitudes about community service learning in the teacher training curriculum. South African Journal of Education, 27:631-654.

Beane JA 2005. Curriculum planning and development. Boston: Allyn and Bacon.

Carl AE 2002. Teacher Empowerment through Curriculum Development ( $\left.2^{\text {nd }} e d\right)$. Lansdowne: Juta and Company.

Coutts A 1992. Multicultural education. Pietermaritzburg: Shuter and Shooters.

Department of Education 1998. Curriculum 2005 Policy Document. Pretoria: Government Printer.

Department of Education 2000. Government Gazette. Pretoria: Government Printer.

Department of Education 2010. Teacher statistics. Pretoria: Government Printer.

Ebersohn, L \& Eloff, I 2002. The black, white and grey of rainbow children coping with HIVIAIDS. Perspectives in education, 20:77-86.

Finch CR \& Crunkilton JR 2004. Curriculum development in vocational and technical education. Boston: Allyn and Bacon.

Fullan M \& Pomfret A 2005. Review of research on curriculum implementation. Toronto: The Ontario Institute for Studies in Education.

Goody TL \& Brophy J 2003. Looking in classrooms. New York: Harper and Row.

Goodson IF 1988. The making of curriculum. London: Falmer Press.

Hoadley U \& Jansen J 2009. Curriculum. Organising knowledge for the classroom. Cape Town: Goodwood.

Marsh JC 2002. Key concepts for understanding curriculum. London: Falmer Press.

Nzimande B 1997. Foreword. In P Kalaway, G Knuss, A Fataar \& G Dunn(eds) Education after apartheid: South African education in transition. Cape Town: University of Cape Town Press.

Pirozzi G 2009. UNICEF. Education and child friendly schools. Available at: http://www. Unicef.org/south Africa/education.html). Accessed 15 October 2011.

Shisana O, Peltzer K, Zungu-Dirwayi N \& Louw JS 2005. The health of our educators. A focus on HIV/AIDS in South African public schools. Report funded by and prepared for the Education Labour Relations Council. Cape Town: HSRC.

Statistics South Africa 2006 September 'Adult mortality (age 15-64) based on death notification data in South Africa: 1997-2004'.

UNAIDS 2010. 'UNAIDS report on the global AIDS epidemic'.

Van Wyk N \& Lemmer E 2007. Redefining home-school-community partnerships in South Africa in the context of the HIVIAIDS pandemic. South African Journal of Education, 27:301-316. 
